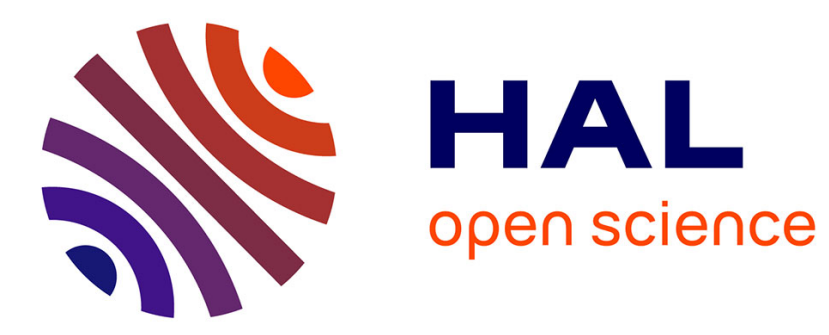

\title{
A System of Tradable CO2 Permits Applied to Fuel Consumption by Motorists
}

Charles Raux, Grégoire Marlot

\section{To cite this version:}

Charles Raux, Grégoire Marlot. A System of Tradable CO2 Permits Applied to Fuel Consumption by Motorists. Transport Policy, 2005, 12 (3), pp. 255-265. 10.1016/j.tranpol.2005.02.006 . halshs00067833

\section{HAL Id: halshs-00067833 \\ https://shs.hal.science/halshs-00067833}

Submitted on 18 Jan 2007

HAL is a multi-disciplinary open access archive for the deposit and dissemination of scientific research documents, whether they are published or not. The documents may come from teaching and research institutions in France or abroad, or from public or private research centers.
L'archive ouverte pluridisciplinaire HAL, est destinée au dépôt et à la diffusion de documents scientifiques de niveau recherche, publiés ou non, émanant des établissements d'enseignement et de recherche français ou étrangers, des laboratoires publics ou privés. 


\title{
A system of tradable $\mathrm{CO}_{2}$ permits applied to fuel consumption by motorists
}

\author{
Charles Raux* \\ Grégoire Marlot \\ Laboratoire d'Economie des Transports (Centre National de la Recherche Scientifique), \\ ISH, 14 av. Berthelot 69363 Lyon Cedex 07, France \\ 18/02/05 11:50 7293 words \\ Classification JEL: D120, D450, R410, R480 \\ Key words: transferable permits, transport, greenhouse gas, surplus
}

\begin{abstract}
Decentralized transferable permit systems in the transport sector can be of interest with regard to reducing greenhouse gas emissions, in spite of anticipated transaction costs. This paper describes a potential application of a domestic market for car fuel consumption permits. The marginal costs of consumption reduction vary sufficiently according to motorists' residential locations to consider permit exchanges. Economic evaluation of this system shows that there are transfers of surplus between the various groups of motorists according to their residential locations. The central government may lose significant revenues when compared with a conventional fuel tax. Lastly, the issue of transaction costs, the benefits and disadvantages in terms of social acceptability and equity are discussed.
\end{abstract}

\section{Acknowledgements}

This paper is based on a research conducted with the support of the CNRS (Centre National de la Recherche Scientifique) and funded by the French Ministry of the Environment. We would also like to thank our colleague Dominique Bouf for his helpful comments on an earlier version of this paper. However views expressed here are solely the authors' ones.

Title abbreviated:

Tradable permits for fuel consumption

Paper published in Transport Policy 12 (2005) 255-265

* corresponding author. Email: charles.raux@let.ish-lyon.cnrs.fr 


\section{Introduction}

At the 1992 Rio Earth Summit and the 1997 Kyoto Conference, the majority of developed countries accepted the creation of legally binding quotas for greenhouse gas emissions (GHGs) with the aim of stabilizing the atmospheric concentration of these gases. The transport sector is one of the main sources of GHGs, and the principal source if we only consider $\mathrm{CO}_{2}$ (the transport sector was responsible for $34 \%$ of French $\mathrm{CO}_{2}$ emissions in 1999, and $30 \%$ of the $\mathrm{CO}_{2}$ emissions in the USA in 1997). In addition, the transport sector has one of the highest potentials for further GHG emission increases. According to an OECD study, the share of GHG emissions from transport could increase from 25\% in 1995 to 30\% in 2020 (OECD, 2000a).

Studies of transport emission reduction strategies (see for instance OECD, 2000b) have all agreed that the foreseeable improvement in car technology is inadequate, within the 20 year time horizon, for countries to meet the Kyoto or Rio objectives. These studies also emphasize the need for approaches that combine technological, economic and social aspects. These "packages" of measures should include a variety of policies for limiting vehicle-kilometres travelled by providing alternatives to the private car, by combating urban sprawl, by increasing public awareness, but also by means of economic instruments such as taxation or transferable permits.

As we shall go on to explain, fuel taxation has limits with regard to efficiency and social acceptability. For this reason, it is worthwhile considering transferable permits as an alternative means for countries to attain their GHG emission level objectives.

The economic theory behind pollution permit markets can be traced back to the work of Coase (1960) on external costs, followed by that of Dales (1968) on regulating water use, and the formalization of pollution permit markets by Montgomery (1972). According to Godard's general definition (in OECD, 2001), transferable permits are a variety of instruments ranging from the introduction of flexibility into conventional regulation to the organization of competitive permit markets. These instruments share the following common features: (1) they involve the fixing of quantified constraints (quotas); (2) these quotas (or rights) are initially allocated to agents independently of the environmental obligations imposed on them; (3) agents are authorized to transfer these quotas between different activities or different places (averaging), between different periods of time (banking) or to other agents (trading); (4) ad hoc penalties are applied to ensure that agents only emit the equivalent of those rights or quotas which they hold.

However, it is generally considered that the large number of moving emission sources which characterize transport constitutes an insurmountable obstacle to the introduction of emission permit markets within this sector. Thus, the only economically efficient response would involve extension of current fuel taxation to include a kind of " $\mathrm{CO}_{2}$ tax". The aim of this paper is to explain briefly what advantages a decentralized transferable permit system in the transport sector has over traditional taxation and to show how a permit system as an alternative to a $\mathrm{CO}_{2}$ tax could work. The case of France is used as an example for practical application.

The first section will discuss the limits of taxation and outline the potential advantages of permit markets in the transport sector. The second section describes a decentralized permit system for motorists: it includes the principles and practical implementation, the socioeconomic evaluation in the French case, and finally equity and acceptability issues. 


\section{The limits of taxation and the potential of transferable permits}

The instrument of taxation is widely used in the transport sector, essentially because of its tax yield. Excise duties levied in the European Union in 2002 varied in member states from $€ 0.296$ to $€ 0.742$ per litre for premium grade petrol and from $€ 0.242$ to $€ 0.742$ per litre for diesel oil (Commission of the European Communities, 2002). In France, fuel excise duties provided the central government with bn€27 in 2002 for a GDP of bn€1,522. Although the current level of taxation might be considered high, it is not high enough to reduce road fuel consumption. The level of taxation required to reduce $\mathrm{CO}_{2}$ emissions can be estimated from the price elasticity of fuel demand ${ }^{1}$, whose value varies depending on whether short-term or long-term effects are taken into account. This is because, in the event of an increase in fuel price, some adaptations such as changes in driving style, reducing or optimizing some trips, or changing transport mode can be implemented in the short-term (for example, in the weeks or the months which follow the price increase). Other adaptations, such as changing one's vehicle, residential location or place of work, take longer. Price elasticity values vary between 0.3 for the short-term and -0.7 for the long-term (Goodwin, 1988). This is ordinary elasticity, related to a marshallian (or non-compensated) demand function, which therefore includes the substitution and income effects.

We can obtain some orders of magnitude by applying a few figures to the case of France. With a price elasticity of -0.7 , a fuel cost of $€ 1.06 / 1$ (as in February 2000) and the objective of reducing consumption by $10 \%$, the price would need to rise by $14 \%$; i.e. an additional $€ 0.15 / 1$ of tax. As a result of a large increase in the price of crude, the price paid by the consumer for premium grade petrol increased by $17 \%$ (from $€ 0.9$ to $€ 1.06$ ) between February 1999 and February 2000. In view of the short-term elasticity, fuel consumption and traffic should have been affected immediately. However, the two parameters continued to rise in 1999 and only stabilized in 2000 before rising again in 2001 (URF, 2003). We can perceive here the effect of the sustained economic growth observed at the end of the 1990s. The amount of tax required to reduce GHG emissions should also therefore take account of the income elasticity of fuel demand, which is positive. In other terms, in order to remain effective in moderating fuel consumption, the tax on fuels should increase at the same rate as the economy grows.

Furthermore, variations in the price of petrol are likely to cancel out the effect of this tax on the end consumer. The turnaround in the oil market that took place in 2001 essentially cancelled out the 1999-2000 price rise, as the price of premium grade unleaded petrol returned to a little under $€ 1$ (the usual level in 2002 and 2003): the price effects of a $\mathrm{CO}_{2}$ tax would have been wiped out.

Lastly, the "tax rebellion" that took place in several European countries in September 2000 shows how sensitive public opinion is to fuel taxation (Lyons and Chatterjee, 2002). Central government is a focus for opposition as it benefits from the tax, although it has little control over oil prices.

Thus, not only do fluctuations in oil prices mean that the effectiveness of a tax is extremely unpredictable, it is also not at all sure that it would be accepted by public opinion. Both these factors encourage us to explore the feasibility of $\mathrm{CO}_{2}$ emission permits in the transport sector.

Theoretical and practical knowledge and the potential for transferable permits in the transport sector have been analyzed by Raux (2004). For transport, transferable permits have some interesting features when compared with taxation:

\footnotetext{
1 the price elasticity of fuel demand is the sensitivity of fuel demand to price: an elasticity of -0.3 means that an increase in price of $10 \%$ yields a decrease in demand of $3 \%$.
} 
- The price response function of agents is affected by a non-negligible degree of uncertainty. Furthermore, the price elasticity of fuel demand is low in the short or medium term: a quantitative objective would be easier to achieve with the permit system than with taxation.

- In view of the high level of fuel taxation in Europe, freely allocated permits would be seen by agents as a means of escaping an additional tax, possibly making the new instrument more acceptable.

- Quota systems are the only systems which allow distributive aspects to be treated in an explicit manner, independently from the issue of the economically efficient allocation of efforts to reduce environmental damage: in view of the fundamental role of transport as regards access to activities and locations, particular attention must be given to these distributive impacts.

- When transferable permits are applied to GHG emissions from transport it is possible to fix precise quantitative objectives for each agent, as overall output is equal to the sum of agents' individual outputs; at planetary level it matters little where GHGs are emitted, and the quotas can be exchanged within a domestic or even planetary geographical area.

A system of transferable permits equalizes the marginal costs of reduction between all emission sources. Under certain assumptions this is a sufficient condition for minimizing the cost of achieving a given emissions reduction objective (Baumol and Oates, 1988). This result is obtained independently of the initial allowance of the rights, which makes it possible to separate the questions of efficiency and equity. However, Stavins (1995) has shown that when transaction costs are involved - the search for partners for the exchange, negotiation, decision-making, follow-up and compliance with the rules - the initial allocation of rights affects the final balance and the total cost of reducing emissions. The authorities may therefore attempt to reduce these transaction costs, for example by avoiding finicky regulations or by facilitating the activity of intermediaries between vendors and purchasers (Hahn and Hester, 1989; Foster and Hahn, 1995).

An economic incentive instrument achieves its maximum efficiency when it operates at the most decentralized level possible. This why we do not deal further with the option of "upstream" permits where the permits would be allocated to fossil fuel producers and importers (Winkelman et al, 2000). The transmission of permit prices by these fuel wholesalers to final consumers would lose the advantages of permits over tax referred to above, without forgetting the issue of acceptability of letting private companies manage the fuel rationing.

This issue of administrative costs is the main argument against the use of permit systems within the transport sector which, by definition, involves a large number of mobile sources. Perhaps this explains why the only application or propositions in the literature are confined to systems targeting auto makers and concerning unitary vehicle emissions (for example, Albrecht, 2000; Wang, 1994; and the ZEV programme in Raux, 2004). The main advantage of these proposals is that the permit systems would involve a small number of participants thus allowing minimum transaction costs. Permits on household car ownership are another indirect way of controlling car travel (Walton, 1997) but the linkage with actual fuel consumption is very crude. These systems have the disadvantage of ignoring the other component of total emissions, fuel consumption through actual vehicle use by drivers.

Controlling land use (Ottensmann, 1998) is in principle an attractive way of reducing distances traveled, but it is controversial - it has still not been proven that it is possible to reverse the tendency to travel longer distances by compacting locations 
again. However, alternatively, the spatial concentration of activities yields more opportunities for cost-efficient transport alternatives, such as mass transit, that are less energy consuming.

Other ideas circulate, encompassing all fossil fuel consumption and not just car fuel: according to these proposals a "carbon allowance" should be given on a per capita basis. The most elaborated proposal is "domestic tradable quotas" by Fleming (1996) which would be allocated partly free to adults and partly by tender to firms and other economic agents. To our knowledge this proposal is still under study and the practical implementation including technical, institutional and equity aspects has not yet been devised. While the idea of "carbon allowance" is attractive, one suspects that its application to every aspect of household energy consumption needs careful investigation and assessment of each one separately, e.g. home heating and family use of energy, transportation and so on.

This is why the following section of the paper proposes and discusses a system of tradable permits on the demand side which targets decisions of motorists regarding their fuel consumption. The main challenge here is to reduce the administrative costs of such a system as much as possible. Such a system would come not as an alternative but as an addition to other systems on the supply side: those targeting auto makers (as referred to above) and potential systems (not yet devised to our knowledge) that could target different levels of government as policymakers in supply of transport infrastructure (e.g. motorways and railways) and services (e.g. public transport).

\section{A system of tradable permits applied to motorists}

We begin by describing, in practical terms, the form that a permit system applied to motorists could take. In the case of France, private cars account for approximately three-fifth of fuel sales, the rest being consumed by light and heavy goods vehicles. We shall then evaluate this system both quantitatively and qualitatively before briefly discussing an extension of it to the freight sector.

\subsection{A tradable permit market}

\section{Obligations and permit holders}

An economic incentive instrument achieves its maximum efficiency when it operates at the most decentralized level possible. In the case we are considering, this is the level of motorists as consumers of fuel and hence emitters of $\mathrm{CO}_{2}$ so it is this group who should hold the permits and have the obligations.

A consumer who purchases motor vehicle fuel (which will necessarily be burnt) will have to transfer the corresponding quotas to the regulating authority. These quotas will then be cancelled. The quota corresponds to an authorization to emit the $\mathrm{CO}_{2}$ equivalent of a litre of fuel ${ }^{2}$. These quotas may be held initially by the agent or purchased from another agent who participates in the permit market.

\footnotetext{
2 Strictly speaking, this value should vary according to the type of fuel: diesel fuel contains more carbon than petrol, gasoline with ETBE can have different emissions than gasoline without ETBE. A conversion factor would apply for each kind of fuel. For the purpose of simplicity of exposition and evaluation in this paper we have assumed that one permit unit corresponds to one litre of any fuel.
} 
Free allocation of permits minimizes problems of social and political acceptability as it allows a certain amount of fuel to be consumed without incurring any additional cost. This means that a minimum level of travel can be guaranteed to all users who possess no viable alternative to the car.

To do this, our starting point can be an average consumption of 1,000 litres per car per year ${ }^{3}$. If we impose a $10 \%$ reduction in this consumption, 900 permits should be allocated (to buy 900 litres at the normal price) per car per year ${ }^{4}$.

The Kyoto protocol in fact only represents a first stage towards achieving more drastic emission reduction objectives. Short-term travel behaviours are to a large degree determined by more long-term location choices - particularly residential ones. The regulating authority should therefore introduce and publicize a regular reduction in the number of permits that are allocated with a rolling horizon of about a decade.

The permits remain valid for an unlimited period, which may lead to hoarding and speculation. However, the $\mathrm{CO}_{2}$-equivalent value of quotas held by an agent will be reduced in the following year in accordance with the rate of the reduction in free permit allocations decided by the regulating authority.

\section{Exchange mechanism}

In order to consume more than 900 litres of fuel, a consumer must purchase additional permits on the market. On the other hand, a consumer who does not use all his/her allocated permits could sell them. The possibility of selling permits provides an additional incentive for modifying one's behaviour, particularly for persons who can do so at low cost.

However, given the huge number of potential participants, the exchange would not be bilateral, but rather centralised through a stock exchange which would yield the daily value of permit. Practically participants would buy and sell permits through intermediates like their usual bank operator or buy them at the petrol pump (see below). This means perfect information of participants about the current price of permit.

\section{Monitoring, verification and penalties}

The sale and purchase of permits will be supervised at national level by a regulatory authority. The permits which are awarded annually will be held on a chipcard which records permit debit and credit operations. This card will be compatible with the automatic teller machines (ATM) that are already installed at petrol stations. Permits can therefore be debited or purchased at the current rate when buying fuel. It will also be possible to purchase or resell permits in banks, using ATM bank distributors or over the Internet.

\footnotetext{
${ }^{3}$ Our quantitative simulations were performed for 1997 which was the most recent year for which data on the car fleet and fuel consumption was available (the SOFRES-ADEME Parc Auto panel, cf. Hivert, 1999). Based on the mileages and unitary consumption figures which are reported by the panel $(13,719$ $\mathrm{km}$ on average, and slightly less than $7.5 \mathrm{l} / 100 \mathrm{~km}$ ) average annual consumption is 1,022 litres.

4 Since the allocation is on annual basis, new incoming participants (e.g. individuals buying their first car) will get the same allocation as other car owners. The increase or decrease of cars will, ceteris paribus, respectively decrease or increase the individual allocation on the following year in order to comply with the overall objective.
} 


\subsection{A combined taxation and permit system}

It would be socially unacceptable to apply suddenly the permits system to all motorists. The current fuel taxation system will be supplemented by the coexistence of two systems: the permits on the one hand, and the extension of taxation with a " $\mathrm{CO}_{2}$ tax" on the other hand. These two systems will be the alternative proposed to motorists and it will be necessary to provide a financial incentive to adopt the permit system.

Also, in order to reduce administrative costs, permit utilization operations will have to be validated as close as possible to the time of fuel purchase, that is to say when the motorist buys fuel at the pump. It will therefore not be possible to create an impenetrable administrative barrier between the system of taxation and the system of permits.

A possible solution is to set up a tax $t$ (in fact the " $\mathrm{CO}_{2}$ tax"), which would be paid both by fuel consumers who are outside the permit market and those who are taking part in it but who have used up their allocation and who are either unable or unwilling to purchase permits on the market. This tax would therefore constitute a price ceiling of permits on the market (Baumol and Oates, 1988).

This tax would have to be calculated with reference to the country's international commitments. If we take the case of France, for example, in view of the fact that the country is committed to stabilizing its emissions to the 1990 level and the increase that has occurred since then, we can make the (optimistic) hypothesis that only a 10\% reduction in emissions will be required in 2008 compared to 1997.

The average price of all fuels at the pump in France in 1997 was €0.85. In order to create a strong incentive to transfer from the tax regime to the permit regime and in view of the uncertainty that affects the price elasticity, the $\mathrm{CO}_{2}$ tax $t$ or permit ceiling price must be based on the most pessimistic elasticity hypothesis, i.e. -0.3: this would correspond to a 33\% increase in the price of fuel (inclusive of tax) i.e. €0.28 in 1997.

Taking part in the permit system could then be voluntary. Motorists would be encouraged to join the permit system as by doing so they would receive a free allocation of permits. The free allocation is linked to an act of economic consumption (possession and use of a car), which moderates the windfall effect caused by the fact that permits are free. The incentive of increasing the number of cars one owns is limited by vehicle insurance and maintenance costs, which are inescapable because periodic vehicle inspection. This windfall effect could only come into play if the cost of permits on the markets became very high: however, the price of permits is bounded by the level of tax $t$.

\subsection{Evaluation of the proposed system in the French case}

In what follows, we shall present two forms of evaluation. The first is quantitative and involves an estimation of the surpluses that result from the operation of a market of this type. The other is qualitative and involves identifying the administrative costs and a discussion of other issues associated with a system of this type. With regard to equity, surplus calculations have the advantage of showing how gains and losses are distributed on the one hand between central government and consumers in general and on the other hand between the different categories of consumers.

\section{Evaluation of the surpluses of the different actors involved}

We shall start by describing the method and hypotheses we have applied to calculate surpluses. We shall then present the results of our calculations. 


\section{Hypotheses and calculation method}

Figure 1 shows a convenient approximation of the demand curve, that is to say change in demanded quantities (motor vehicle fuel, on the x-axis of this graph) as a function of the price (on the $y$-axis). The current exclusive of tax price $\left(\mathrm{P}_{0}\right)$ corresponds to that part of the price that is paid to the distributor. To this is added current taxation (VAT and excise duty) which is considered as a lump sum paid into the treasury, i.e. the price $\mathrm{P}_{1}$. Adding a $\mathrm{CO}_{2}$ tax with the level of $t$ (the price of the permit) will increase the price to $\mathrm{P}_{2}$.

Given the uncertainty of price response function of fuel consumers we can only hypothesize values for the price-elasticity of demand, which as stated above vary between -0.3 (short-term elasticity) and -0.7 (long-term elasticity). These values give an indication of the tax range that should be imposed a priori by the central government in order to achieve possibly the consumption reduction objective. As shown above the mechanism of permits would guarantee the quantitative objective in presence of uncertainty of price response function. Consistently with our hypotheses about priceelasticity of demand, the equilibrium price of the permit would be identical to the optimal tax in order to achieve the same consumption reduction result. This why the permit price is deliberately set at the same level of the tax in our evaluation.

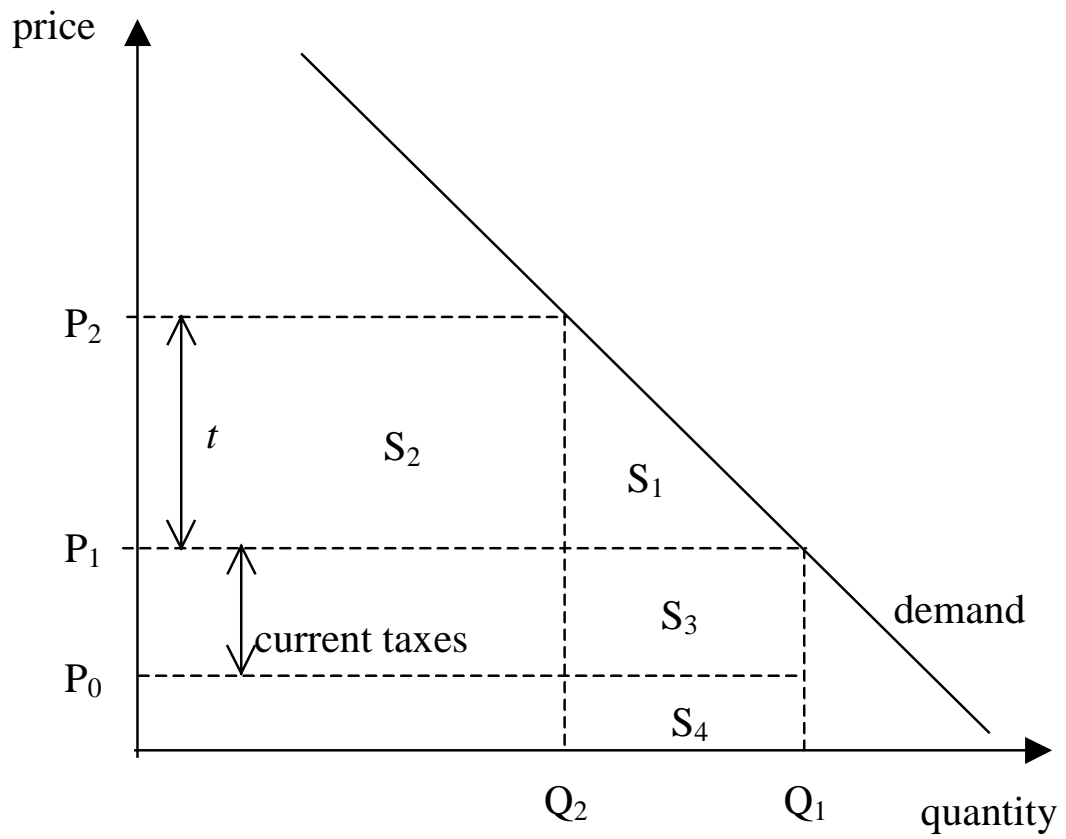

Figure 1: The effects of taxes on the demanded quantities of fuel and the distribution of surpluses

The transition from a price of $\mathrm{P}_{1}$ to a price of $\mathrm{P}_{2}$ will result in a modification of behaviours, which will in turn reduce fuel demand, from $\mathrm{Q}_{1}$ to $\mathrm{Q}_{2}$. The resulting surpluses will be as follows ${ }^{5}$ :

- $\mathrm{S}_{1}$ represents the loss in consumer surplus resulting, for example, from the reduction of trip-making or the purchase of a more fuel-efficient but more expensive car: this loss is net of the cost of the fuel that is no longer consumed $\left(\mathrm{Q}_{1}-\mathrm{Q}_{2}\right) \cdot \mathrm{P}_{1}$.

\footnotetext{
${ }^{5}$ In what follows, the surpluses are considered to be positive for the agents who benefit from a gain and negative for the agents who suffer a loss.
} 
- $\mathrm{S}_{2}$ represents, in the case of taxation, the gain in central government's surplus that results from the newly paid tax on the fuel that is consumed $\mathrm{Q}_{2} . \mathrm{S}_{2}$ is a loss for consumers. In the case of permits, central government is no longer involved and $\mathrm{S}_{2}$ represents, for consumers, the gains that result from the sale of permits or the losses that result from the purchase of permits.

- $\mathrm{S}_{3}$ represents the loss in the surplus of central government as a result of taxes which are no longer paid on the fuel which is no longer consumed $\left(\mathrm{Q}_{1}-\mathrm{Q}_{2}\right)$.

- $\mathrm{S}_{4}$ represents the loss in the surplus of other agents (distributors, refiners, oil producers, etc.) because the amount of fuel $\left(\mathrm{Q}_{1}-\mathrm{Q}_{2}\right)$ is no longer consumed: this quantity $\mathrm{S}_{4}$ is the same whether we consider the tax or permits: thus it does not interfere in the comparison of the two instruments.

The surplus for fuel consumers is $\left(\mathrm{S}_{1}-\mathrm{S}_{2}\right)$. The surplus for central government is $\left(S_{2}+S_{3}\right)$ when the tax is applied and $S_{3}$ in the case of permits. The overall surplus for society is $\left(\mathrm{S}_{1}+\mathrm{S}_{3}+\mathrm{S}_{4}\right)$. In these calculations, it has been assumed that variation in demand does not affect the price of fuel before tax $\mathrm{P}_{0}$.

In addition, as we are only comparing the tax with the permits, we take no account of gains in congestion, accidents, local pollution and noise which would result from a reduction in traffic, as these gains are similar in both cases.

Since we are evaluating different policy options to obtain a given quantitative objective of emission reduction, the overall surplus change regarding transport behaviour will be negative: this has to be compared with the infinite costs associated with climatic change which would be avoided if emissions are reduced according to the objective set by international agreements. Moreover in our exercise the overall surplus change is the same when comparing tax and permits. The differences between the two instruments lie in the distributions of surplus between categories of motorists and between motorists and the central government.

Consumers must modify their behaviours in order to reduce fuel consumption, in particular by reducing vehicle-kilometres travelled: the difficulty of this adaptation will depend on the closeness of jobs, shops and services, and supply of alternative transport modes to the car. An essential dimension therefore is the type of residential area.

Statistics concerning traffic levels and fuel consumption according to type of residential location are provided by the INRETS analysis mentioned above (Hivert, 1999): this study distinguishes four types of location: the city centre, the suburbs, the periurban zone and rural areas ${ }^{6}$.

As we do not have detailed knowledge about the elasticities for the different categories of motorists according to their residential location, we have had to hypothesize elasticity values for these four groups of motorists: it is reasonable to assume that elasticity is highest (in absolute value) for persons living in the city centre (who are the nearest to activities and who have the best public transport supply) and that this elasticity decreases as one moves towards rural zones. These values are adjusted so as to obtain the average overall elasticity level, on the basis of the percentage of vehicles originating in each category of residential location.

Using the four elasticity values we then calculate the average surpluses for each vehicle $S_{1}, S_{2}, S_{3}, S_{4}$, the total surplus for motorists, central government and the other actors, then the average values of these surpluses per vehicle. This calculation has been conducted for two average overall elasticity values, -0.3 and -0.7 , and for the situation with taxation and the situation with permits. The detailed results of these calculations are given in the appendix.

6 This coding was developed by INRETS, $c f$. Madre and Massot, 1994. 


\section{Results}

An initial comparison between the tax and the permits can be made firstly on a global basis without distinguishing between different types of residential location.

For each average elasticity value, the total surpluses and "other surpluses" $\left(\mathrm{S}_{4}\right)$ are identical by construction in the case of the tax and the permits. The essential difference between these two systems results from the transfers between motorists and central government.

In the case of the tax and with an elasticity of -0.3 , which is the least favourable adaptation hypothesis, motorists as a group lose almost bn€7.2 and central government gains almost bn€5.1 (see Table 1 in the appendix). With an elasticity of -0.7 , these values are respectively bn€3 and bn€1.2 (Table 3). As a matter of interest, the total tax collected on fuels amounted to approximately bn€30.5 in 1998, of which bn€23.6 came from excise duty. For these two elasticity values, the average additional annual tax levy per vehicle would be respectively $€ 275$ and $€ 118$ (Table 1 bis and Table 3bis).

In the case of permits, these transfers are very much reduced because of the initial free permit allocation. For each of the two elasticity values $(-0.3$ and -0.7$)$ motorists as a group would lose respectively $€ 374 \mathrm{M}$ (Table 2) and $€ 161 \mathrm{M}$ (Table 4), the annual loss per vehicle would be respectively $€ 14$ and $€ 6$ (Table 2bis and Table 4bis).

The dramatic change is experienced by central government as, with the permits, it loses more than bn€1.7 of tax revenue (Table 2 and Table 4). This is the result of the loss $\mathrm{S}_{3}$, due to the reduction in the amounts of fuel consumed, which are not compensated for by an additional tax which does not exist as there is redistribution between motorists as a result of permit exchanges.

Next, we can make a second comparison by observing what happens for different categories of households on the basis of residential location. On average, with the tax, the per vehicle tax levies differ by a maximum of fifty euros per year in the least favourable case (elasticity of -0.3 , Table 1 bis) and by about fifteen euros in the other case (Table 3bis).

The situation is of course different in the case of the permits. The volume of permit exchanges will vary according to our hypothesis concerning the elasticities for the different categories of households and the average overall elasticity.

In the least favourable adaptation situation (elasticity of -0.3), approximately 1.4 billion permits would be exchanged (Table 2ter): this figure is to be compared with fuel consumption of 26 billion litres. Households who live in city centres or the suburbs would, on average, be vendors. The monetary gain would compensate for the loss $S_{1}$ due to their lower consumption: there would be a net, but low, per vehicle gain (an average of $€ 9$ and $€ 3$ respectively over one year, see Table 2bis). Inhabitants of the periurban zone would on average be the largest purchasers and would make an average loss of €41 per vehicle over one year.

In the case of an elasticity of -0.7 , about 1 billion permits would be exchanged (Table 4ter). In this case too, households located in the city centre or the suburbs would be vendors (Table 4bis). This monetary gain would just compensate for the loss that would result from the reduction in their consumption. In this case too, the biggest purchasers would be those living in the periurban areas and this group would suffer an average net loss of $€ 16$ per vehicle over the year, more than three times that of rural households (€5).

These quantitative results should, of course, only be seen as providing an order of magnitude for a possible distribution of surpluses, on the basis of the hypotheses made concerning the different elasticities according to the type of residential location. 
However, on the basis of these results, we can identify three factors that merit further discussion.

First, the comparison between taxation and permits in this case involves the fiscal gain in the case of the tax and the fiscal loss for the central government in the case of permits. Nevertheless, this loss would only represent approximately $5 \%$ of current fiscal revenue from fuel consumption.

Second, the tax has very little effect on the distribution of surpluses between households according to their type of residential location, as the tax levy is already very high in all cases: all motorists "lose" to the benefit of society.

Third, in the case of permits, the above tax levy disappears and residential location plays a fundamental role: the main winners are households living in the city centre or the suburbs who, on average, sell permits (they can more easily save fuel, therefore permits, by reducing their vehicle-kilometres travelled) while the households living in periurban areas are on average the largest purchasers. The orders of magnitude are of a few euros or tens of Euros of net gains or losses on average every year for each vehicle and between each category of location. Although these sums might seem small at first sight, it should be remembered that they are average results per category of motorists and may cover extremely varied adjustment behaviours.

\subsection{Administrative costs}

The costs of setting up and administering the system would include:

- altering the software in the ATM at petrol stations so they can deal with the permit system (reading the balance, debiting);

- manufacturing and distributing chipcards, or installing the microcode software on existing bank chip cards during periodic replacement;

- the information campaign for this new system of transactions;

- managing the permit exchange market which could be included in the stock exchange.

In view of the fact that the transactions and verifications required for the permits will be highly integrated with the current system of credit card transactions, these costs should be moderate. Furthermore, they could be covered by a fee charged on each permit exchanged, which would be extremely low in view of the high volumes involved.

\subsection{Other characteristics}

This system has the advantage of simplicity, as the unit of exchange is the permit for each litre of fuel that is consumed. The amounts consumed or exchanged are therefore monitored when fuel is purchased, and all persons who purchase fuel can participate in the market (see below for the case of commercial vehicles): monitoring is therefore straightforward as it only involves fuel purchases. The fact that the tax $t$ sets an upper bound for the price of permits and the possibility of freely exchanging permits will discourage any tendency for a black market to develop.

A similar system could also be introduced for freight and public transport vehicles. However, international competition between carriers plays an important role and regulates the transport market: this means that a permit system for commercial vehicles would have to operate at least at European Union level. Furthermore, the 
political difficulties involved in introducing taxes or permits in the road freight transport sector as a result of the economic fragility of many companies, should not be forgotten.

Should the permit market for the transport sector be closed or open to a national or international cross-sector permit market?

Fluctuations in the market price of permits will indicate their scarcity and the need for any adjustments. If too few permits are allocated, the price of the permits will tend to rise: however, this price is bounded by the tax $t$.

This kind of permits market could at the beginning operate mainly on a domestic basis: it would be viable in view of the generally short distances involved in car trips and if we ignore the impact of "tank tourism" at borders. The risk of this should be quite limited as France's neighbouring countries are also committed to reduce their emissions within the EU bubble: these countries will also have to implement either a " $\mathrm{CO}_{2}$ tax" or a permit system. However the autonomy of each central government in fuel taxation is limited by the behaviour of its neighbouring countries as shown by the current difficulties in fuel taxation harmonisation within the EU.

If the permit market for the transport sector is closed, the price of a permit on this market could be compared with the price of a permit on another national or international market, on the basis of carbon content. It would thus be possible to assess whether the transport sector is being subjected to lower, similar or higher pressure than the others. If the pressure is insufficient, it would mean that the other sectors would have to compensate for it or that central government would have to finance the difference by buying permits on the international market. By closing the market, central government can thus decide to concentrate its efforts on one sector rather than another, for a variety of social or political reasons.

In general, if markets are closed each other, the marginal costs of reducing $\mathrm{CO}_{2}$ emissions are likely not to be the same in different sectors. Distortions of this type will reduce the efficiency of the system. Closure of the market can therefore only be considered as a temporary measure. Ultimately, the permits market system should be open, that is to say that everyone in the country emitting GHGs in different sectors of activity would be able to exchange rights on the same market.

\subsection{Acceptability and equity issues}

If we consider the development of more stringent objectives of emissions reduction in the future, a fuel rationing seems unavoidable: this rationing can basically take the form of either price (tax) rationing or quantities (permits) rationing. From this point of view the issue of acceptability of rationing is an identical precondition for the two instruments and needs at least information campaign and political willpower in order to introduce any emission control measure. This is the first step which needs to be achieved 7 . This is in this context of "accepted rationing" that we can evaluate the relative acceptability of permits.

The free allocation of emission rights creates income which is distributed between the consumers of fuel. In addition, these consumers are strongly encouraged to reduce their consumption as they can make a real and tangible profit from selling their unused permits.

\footnotetext{
7 Recent examples show that opinion can rapidly and significantly change and accept "unpleasant" policies. This is the case of congestion charging in London supported by a strong political willingness of the candidate and then Mayor of London Ken Livingston. This is also the case with the stronger enforcement of speed limits decided in September 2002 in France by the government: this policy overcome decades of laxity and increase of road fatalities.
} 
If all vehicles are allocated the same number of permits problems of equity can arise as a result of specific constraints of use: families with children, disabled persons, persons living in rural areas, etc. There is no reason why the free allocation of permits should not be based on socioeconomic characteristics. It would also be possible for permits to be allocated to each individual, irrespective of their age and whether they own a car.

If we consider again the French case study, this system penalizes high income households more than others: the data from 1997 (Hivert, 1999) show that the average per kilometre mileage for each vehicle increases fairly steadily with income bracket, from slightly more than 12,000 km for the lowest income brackets (less than 11.4 thousand euros per year) to almost $16,000 \mathrm{~km}$ for the highest income brackets (more than 61 thousand euros per year).

Lastly, the initial free allocation avoids imposing an excessive burden on consumers, particularly the least well off. The average annual consumption of cars varies from slightly more than 900 litres (for the lowest incomes) to 1300 or 1400 litres (for the highest incomes), while the proportion of mileage that is covered on home-towork trips varies between 24\% (for the lowest incomes) and 30 or even 39\% for the highest income groups. These figures show that "necessary" travel would generally not be affected. However, this average data should not obscure a possible existence of situations of fragility, for example the "rural poor" who have no alternative but the car; such situations would require ad hoc compensation.

\section{Conclusion}

In this paper we have shown how decentralized transferable permit systems for the transport sector are of interest with regard to reducing greenhouse gas emissions, in spite of anticipated transaction costs. Next, a system of tradable permits for motorists has been described, and its technical and economic feasibility investigated: the marginal costs of depollution vary sufficiently according to motorists' residential locations for us to envisage permit exchanges. Last, we have outlined an evaluation of the socioeconomic consequences of this market operation and the surpluses that would result from it, with plausible elasticities derived from empirical studies.

These simulations have shown that with a system of permits that can be transferred between motorists, central government would only lose $5 \%$ of its fiscal revenue from fuel taxes. The loss in surplus for motorists would be of the order of $€ 10$ per vehicle on average in the case of permits as opposed to between $€ 100$ to $€ 275$ on average in the case of a $\mathrm{CO}_{2}$ emission tax: this is obviously a factor that supports the acceptability of a permit system. The number of exchanges would be large, of the order of one billion permits per year (with a cost of between $€ 0.12$ and $€ 0.28$ per permit). Residents of city centres and suburbs would, on average, tend to sell permits while those in periurban areas or in rural areas would tend to purchase them.

One of the main objections to the application of a system of tradable permits to the transport sector is the large number of actors involved. The resulting transaction costs would be too high for the system to be effective. The system that we have described in this paper overcomes many of these constraints. Its implementation would nevertheless be complex and administratively more costly than a simple increase in fuel taxation.

However, this system does provide strong incentives for reducing consumption because of the concrete, tangible, benefits perceived by those who reduce their emissions below their initial allocation. The free allocation of permits furthermore 
provides a means of overcoming problems of accessibility and equity which would be posed by the addition of a new tax on an already heavily taxed product such as fuel.

Another advantage of this system is that a permit based on the carbon content of fuel can be directly linked with the world market for permits in order to avoid inefficient price distortions between these markets. Nevertheless, central government could maintain complete control over the domestic market and would thus be able to protect it from fluctuations on the world market.

\section{References}

Albrecht, J., 2000. 'The diffusion of cleaner vehicles in CO2 emission trading designs'. Transportation Research Part D, 5:385-401.

Baumol, W. and Oates, W., 1988. The theory of environmental policy, Cambridge University Press, Cambridge.

Commission of the European Communities, 2002. Proposal for a Council Directive amending Directive 92/81/EEC and Directive 92/82/EEC to introduce special tax arrangements for diesel fuel used for commercial purposes and to align the excise duties on petrol and diesel fuel. COM(2002) 410 final, Brussels, November 2002.

Fleming, D., 1996. Stopping the traffic, Country Life, vol 140, 19, pp 62-65. See also www.dtqs.org

Goodwin, P.B., 1988. Evidence on car and public transport demand elasticities 19801988, TSU Ref 427, Oxford, June 1988.

Hivert, L., 1999. Le parc automobile des ménages. Etude en fin d’année 1997. Rapport de convention INRETS-ADEME. INRETS, Arcueil, Juin 1999.

Lyons, A. and Chatterjee, K. (eds), 2002. Transport Lessons from the Fuel Tax Protests of 2000, Ashgate, Aldershot.

Madre, J.L. and Massot, M.H., 1994. Comment décrire l'étalement urbain à partir des nomenclatures de l'INSEE ? Note interne INRETS, Arcueil.

OECD, 2000a. Environmental Outlook, Draft, October 2000.

OECD, 2000b. Environmentally Sustainable Transport. Futures, Strategies and Best Practices. Synthesis report. October 2000; Paris, OECD.

OECD, 2001. Domestic Transferable Permits Systems for Environmental Management. Design and Implementation. OECD, Paris.

Ottensmann, J.R., 1998. Market-based exchanges of rights within a system of performance zoning, Planning \& Markets, Vol 1, Number 1.

Raux, C., 2004. The use of transferable permits in transport policy. Transportation Research Part D, 9(3), pp 185-197. 
URF, 2003. Faits et Chiffres. Statistiques du transport en France. Union Routière de France, Paris, Septembre 2003.

Walton, W., 1997. The potential scope for the application of pollution permits to reducing car ownership in the UK, Transport Policy, April 1997, 4(2), pp. 115-122.

Wang, M.Q., 1994. Cost savings of using a marketable permit system for regulating light duty vehicle emissions, Transport Policy, 1: 221-232.

Winkelman, S., Hargrave, T., Vanderlan, C, 2000. Transportation and domestic greenhouse gas emission trading. Center for Clean Air Policy, Washington DC. April 2000, 32 p.

Coase, R., 1960. The problem of Social Cost. Journal of Law and Economics, 3: 1-44.

Dales, J.H., 1968. Land, water and ownership. Canadian Journal of Economics, 1: 797804.

Montgomery, W.D., 1972. Markets and licenses and efficient pollution control programs. Journal of Economic Theory, 5: 395-418.

Stavins, R., 1995. Transaction costs and tradable permits. Journal of Environmental Economics and Management, 29:133-148.

Hahn, R. and Hester, G., 1989. Marketable permits: lessons for theory and practice. Ecology Law Quarterly, 16:361-406.

Foster, V. and Hahn, R., 1995. Designing more efficient markets: lessons from Los Angeles Smog Control. Journal of Law and Economics, 38:19-48.

\section{Appendix}


Mean elasticity -0.3

\begin{tabular}{|c|r|r|r|r|r|r|r|}
\hline & Location & $\begin{array}{c}\text { average } \\
\text { total } \\
\text { estimated } \\
\text { elasticity }\end{array}$ & $\begin{array}{c}\text { average vkt } \\
\text { consum. } \\
(1)\end{array}$ & $\begin{array}{c}\text { litres / } \\
100 \mathrm{~km} \\
(2)\end{array}$ & $\begin{array}{c}\text { variation in } \\
\text { average } \\
\text { consum. } \\
(4)\end{array}$ & $\begin{array}{c}\text { vehicles } \\
\text { (million) } \\
(5)\end{array}$ & $\begin{array}{c}\text { \% of } \\
\text { vehicles }\end{array}$ \\
\hline city centre & -0.55 & 12918 & 980 & 7.58 & -179 & 7.2 & 27 \\
suburbs & -0.40 & 12869 & 977 & 7.59 & -130 & 7.3 & 28 \\
periurban & -0.10 & 14809 & 1085 & 7.33 & -36 & 10.7 & 41 \\
rural & -0.05 & 14035 & 988 & 7.04 & -16 & 1.0 & 4 \\
\hline average & $\mathbf{- 0 . 3}$ & $\mathbf{1 3 7 1 9}$ & $\mathbf{1 0 2 2}$ & $\mathbf{7 . 4 6}$ & $\mathbf{- 1 0 1}$ & 26.2 & 100 \\
\hline
\end{tabular}

\begin{tabular}{|lr|}
\hline Average price in 1997 $(€)$ & 0.85 \\
of which existing taxes & 0.65 \\
Tax or permit price & 0.28 \\
Initial price + tax & 1.13 \\
Permit allocation (litres) & 921 \\
\hline
\end{tabular}

(1) per vehicle per year. Based on survey findings

(2) in litres / vehicle per year. Based on survey findings

(3) ratio between (1) and (2)

(4) in litres / vehicle. Application of price elasticity

(5) based on survey findings

\section{change in surplus with fuel tax}

average per vehicle

\begin{tabular}{|c|r|r|r|r|} 
& & & & \\
& S1 & S2 & S3 & S4 \\
Location & $(€)$ & $(€)$ & $(€)$ & $(€)$ \\
\hline city centre & -25 & 226 & -117 & -36 \\
suburbs & -18 & 240 & -85 & -26 \\
periurban & -5 & 297 & -23 & -7 \\
rural & -2 & 275 & -11 & -3 \\
\hline
\end{tabular}

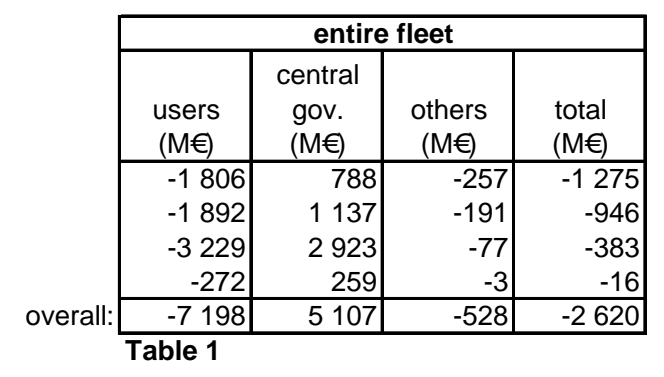

change in surplus with permit average per vehicle

\begin{tabular}{|c|r|r|r|r|}
\hline & & & & \\
Location & S1 & S2 & S3 & S4 \\
\hline city centre & -25 & $(€)$ & $(€)$ & $(€)$ \\
suburbs & -18 & 21 & -117 & -36 \\
periurban & -5 & -36 & -85 & -26 \\
rural & -2 & -14 & -11 & -7 \\
\hline
\end{tabular}

\begin{tabular}{|r|r|r|r|}
\hline \multicolumn{4}{|c|}{ entire fleet } \\
\hline $\begin{array}{c}\text { users } \\
(\mathrm{M} €)\end{array}$ & $\begin{array}{c}\text { central } \\
\text { gov. } \\
(\mathrm{M} €)\end{array}$ & $\begin{array}{c}\text { others } \\
(\mathrm{M} €)\end{array}$ & $\begin{array}{c}\text { total } \\
(\mathrm{M} €)\end{array}$ \\
\hline 64 & -836 & -257 & -1029 \\
20 & -620 & -191 & -791 \\
-441 & -251 & -77 & -770 \\
-16 & -10 & -3 & -30 \\
\hline-374 & -1718 & -528 & -2620 \\
\hline
\end{tabular}

\begin{tabular}{|c|c|r|r|}
\hline \multicolumn{4}{|c|}{ average per vehicle } \\
\hline $\begin{array}{c}\text { user } \\
(€)\end{array}$ & $\begin{array}{c}\text { central } \\
\text { gov. } \\
(€)\end{array}$ & $\begin{array}{c}\text { others } \\
(€)\end{array}$ & $\begin{array}{c}\text { total } \\
(€)\end{array}$ \\
\hline-252 & 110 & -36 & -178 \\
-258 & 155 & -26 & -129 \\
-302 & 273 & -7 & -36 \\
-277 & 264 & -3 & -16 \\
\hline-275 & 195 & -20 & -100 \\
\hline
\end{tabular}

Table 1bis

\begin{tabular}{|c|c|c|c|c|c|}
\hline \multicolumn{4}{|c|}{ average per vehicle } & \multirow[b]{2}{*}{ Location } & \multirow[b]{2}{*}{$\begin{array}{l}\text { permit } \\
\text { exchanges } \\
\text { (millions) }\end{array}$} \\
\hline $\begin{array}{c}\text { user } \\
(€)\end{array}$ & $\begin{array}{c}\text { central } \\
\text { gov. } \\
(€) \\
\end{array}$ & $\begin{array}{l}\text { others } \\
(€)\end{array}$ & $\begin{array}{c}\text { total } \\
(€)\end{array}$ & & \\
\hline 9 & -117 & -36 & -144 & city centre & 870 \\
\hline 3 & -85 & -26 & -108 & suburbs & 546 \\
\hline-41 & -23 & -7 & -72 & periurban & -1367 \\
\hline-16 & -11 & -3 & -30 & rural & -49 \\
\hline-14 & -66 & -20 & -100 & & 0 \\
\hline
\end{tabular}


Mean elasticity -0.7

\begin{tabular}{|c|r|r|r|r|r|r|r|}
\hline & $\begin{array}{c}\text { estimated } \\
\text { Llasticity }\end{array}$ & $\begin{array}{c}\text { average vkt } \\
(1)\end{array}$ & $\begin{array}{c}\text { average } \\
\text { total } \\
\text { consum. } \\
(2)\end{array}$ & $\begin{array}{c}\text { litres / } \\
100 \mathrm{~km} \\
(3)\end{array}$ & $\begin{array}{c}\text { variation in } \\
\text { average } \\
\text { consum. } \\
(4)\end{array}$ & $\begin{array}{c}\text { vehicles } \\
\text { (million) } \\
(5)\end{array}$ & $\begin{array}{c}\text { \% of } \\
\text { vehicles }\end{array}$ \\
\hline city centre & -1.00 & 12918 & 980 & 7.58 & -139 & 7.2 & 27 \\
suburbs & -0.85 & 12869 & 977 & 7.59 & -118 & 7.3 & 28 \\
periurban & -0.45 & 14809 & 1085 & 7.33 & -70 & 10.7 & 41 \\
rural & -0.40 & 14035 & 988 & 7.04 & -56 & 1.0 & 4 \\
\hline average & $-\mathbf{0 . 7}$ & $\mathbf{1 3 7 1 9}$ & $\mathbf{1 0 2 2}$ & $\mathbf{7 . 4 6}$ & $\mathbf{- 1 0 2}$ & 26.2 & 100 \\
\hline
\end{tabular}

\begin{tabular}{|lr|}
\hline Average price in $1997(€)$ & 0.85 \\
of which existing taxes & 0.65 \\
Tax or permit price & 0.12 \\
Initial price + tax & 0.97 \\
Permit allocation (litres) & 921 \\
\hline
\end{tabular}

(1) per vehicle per year. Based on survey findings

(2) in litres / vehicle per year. Based on survey findings

(3) ratio between (1) and (2)

(4) in litres / vehicle. Application of price elasticity

(5) based on survey findings

\section{change in surplus with fuel tax}

average per vehicle

\begin{tabular}{|c|c|c|c|c|}
\hline Location & $\begin{array}{l}\text { S1 } \\
(€)\end{array}$ & $\begin{array}{l}\text { S2 } \\
(€)\end{array}$ & $\begin{array}{l}\text { S3 } \\
(€)\end{array}$ & $\begin{array}{l}\text { S4 } \\
(€)\end{array}$ \\
\hline city centre & -8 & 102 & -91 & -28 \\
\hline suburbs & -7 & 104 & -77 & -24 \\
\hline periurban & -4 & 123 & -45 & -14 \\
\hline rural & -3 & 113 & -37 & -11 \\
\hline
\end{tabular}

$-11$

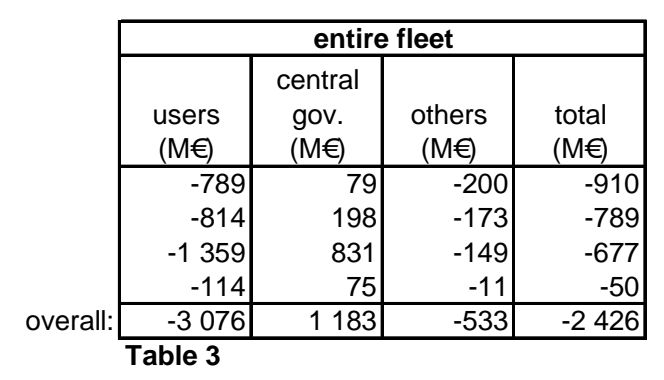

change in surplus with permit

\begin{tabular}{|c|c|c|c|c|}
\hline Location & $\begin{array}{l}\text { S1 } \\
(€)\end{array}$ & $\begin{array}{l}\text { S2 } \\
(€)\end{array}$ & $\begin{array}{l}\text { S3 } \\
(€) \\
\end{array}$ & $\begin{array}{l}\text { S4 } \\
(€)\end{array}$ \\
\hline city centre & -8 & 10 & -91 & -28 \\
\hline suburbs & -7 & 7 & -77 & -24 \\
\hline periurban & -4 & -12 & -45 & -14 \\
\hline rural & -3 & -1 & -37 & -11 \\
\hline
\end{tabular}

\begin{tabular}{|c|r|r|r|}
\hline \multicolumn{4}{|c|}{ average per vehicle } \\
\hline $\begin{array}{c}\text { user } \\
(€)\end{array}$ & $\begin{array}{c}\text { central } \\
\text { gov. } \\
(€)\end{array}$ & $\begin{array}{c}\text { others } \\
(€)\end{array}$ & $\begin{array}{c}\text { total } \\
(€)\end{array}$ \\
\hline-110 & 11 & -28 & -127 \\
-111 & 27 & -24 & -108 \\
-127 & 78 & -14 & -63 \\
-116 & 76 & -11 & -51 \\
\hline-118 & 45 & -20 & -93 \\
\hline
\end{tabular}

Table 3bis

\begin{tabular}{|c|c|c|c|c|c|}
\hline \multicolumn{4}{|c|}{ average per vehicle } & \multirow[b]{2}{*}{ Location } & \multirow[b]{2}{*}{$\begin{array}{l}\text { permit } \\
\text { exchanges } \\
\text { (millions) }\end{array}$} \\
\hline $\begin{array}{c}\text { user } \\
(€)\end{array}$ & $\begin{array}{c}\text { central } \\
\text { gov. } \\
(€) \\
\end{array}$ & $\begin{array}{l}\text { others } \\
(€)\end{array}$ & $\begin{array}{c}\text { total } \\
(€)\end{array}$ & & \\
\hline 1 & -91 & -28 & -117 & city centre & 577 \\
\hline 0 & -77 & -24 & -100 & suburbs & 453 \\
\hline-16 & -45 & -14 & -75 & periurban & -1019 \\
\hline-5 & -37 & -11 & -53 & rural & -11 \\
\hline-6 & -66 & -20 & -93 & & 0 \\
\hline
\end{tabular}

